\title{
KAIIAN TRANSPORTASI SUNGAI UNTUK MENGHIDUPKAN KAWASAN TEPIAN SUNGAI KAHAYAN KOTA PALANGKARAYA
}

\author{
A Study Of River Transportation \\ to Support a Kahayan Riverside Area in Palangkaraya City
}

\author{
Noor Hamidah¹, R. Rijanta² Bakti Setiawan³ Muh. Aris Marfai²
}

Diterima : 17 Oktober 2013 Disetujui: 15 Januari 2014

\begin{abstract}
Abstrak: Sungai merupakan transportasi awal penghubung antara kota-desa dan urat nadi kehidupan ekonomi masyarakat. Seiring perkembangannya transportasi darat menjadi andalan untuk penghubung antar kota-desa. Transportasi sungai tidak menjadi prioritas dalam pengembangan infrastruktur kota,hal ini disebabkan transportasi darat memiliki keunggulan mudah, murah dan cepat dibanding transportasi sungai. Sungai kini menjadi bagian yang tidak diprioritaskan dalam fasilitas pendukung kota, sehingga sungai menjadi bagian belakang yang menimbulkan berbagai permasalahan fisik dan lingkungan bagi kota. Sungai hanya digunakan untuk masyarakat menengah ke bawah dengan pertimbangan migran membutuhkan ruang untuk tempat tinggal yang murah,dekat dengan pusat kota walaupun berada di kawasan jalur hijau yang rawan banjir yaitu di sepanjang tepian sungai ini. Penelitian ini mencoba mengangkat permasalahan yang terjadi pada transportasi sungai berlokasi di kawasan tepian Sungai Kahayan Kota Palangkaraya. Tujuan penelitian ini untuk melihat potensi transportasi sungai dan keunikan moda transportasi Sungai Kahayan Kota Palangkaraya, Kalimantan Tengah.
\end{abstract}

Kata Kunci: Potensi, Transportasi Sungai, Menghidupkan, Kawasan Tepian Sungai, Kahayan, Kota Palangkaraya

Abstract: River is a first transportation for connection city to village and central for economic community. Nowadays, land transportation is a trend for connection city to village. River transportation have been not priority, due to land transportation more easy to access, low cost and faster rather than river transportation. River have been not priority for infrastructure and river is a backward. River is facing serious problems such as physical and environmental problem. River are still occupy for lower income people as a reason house can built by themselves and close to work location with a location in green belt area. Thispaper try to arguehow is a problem in river transportation. The location of this research is Kahayan River, Palangkaraya City. This research aim is to reveal of potential of river transportation and unique of moda transportation will be revitalize of Kahayan riverside area of Palangkaraya City, Central Kalimantan.

Keywords: Potency, river transportation, revitalize, Riverside area, Kahayan, Palangkaraya city

\footnotetext{
${ }^{1}$ Jurusan Arsitektur, Fakultas Teknik, Universitas Palangkaraya

2 Jurusan Geografi, Fakultas Geografi, Universitas Gadjahmada

3 Jurusan Arsitektur, Fakultas Teknik, Universitas Gadjahmada
} 


\section{Pendahuluan}

Keunikan Indonesia ialah kekayaan lingkungan alamnya yang merupakan kepulauan terbesar di dunia, terdiri dari sekitar 17.508 pulau yang membentang sepanjang $5.210 \mathrm{~km}$ dari timur ke barat dan dihuni oleh sekitar 300 suku bangsa dengan 583 bahasa dan dialek. Terdiri dari 34 Propinsi dengan keaneka-ragaman sifat lingkungannya dan terdapat berbagai tempat permukiman pedalaman yang penduduknya lebih berorientasi dan mempunyai akses ke daerah pedalamannya, antara lain melalui sungai-sungai yang menghubungkan penduduk di hulu dan hilir sungai, seperti masyarakat Dayak di Kalimantan dan masyarakat Kubu di Sumatera. (Indonesia Heritage, 1992: 8-9).

Kota-kota di Kalimantan memiliki kondisi geografis yang unik yaitu awalnya dari tepian/bantaran sungai, daerah rawa, dan hutan belantara. Kota-kota di Kalimantan digambarkan sebagai "Kota Sungai" karena banyaknya sungai yang membelah kota dan menjadi sumber kehidupan masyarakatnya. Demikian pula halnya dengan kota-kota di Provinsi Kalimantan Tengah yaitu: Palangkaraya, Kuala Kapuas, Pangkalanbun, Muara Teweh, Buntok dan lain-lain yang terletak di tepian Sungai Barito dan Sungai Kahayan.

Tautan lingkungan alami tercermin melalui karakteristik fisik ini merupakan sifat alami, dimana sungai memiliki keunikan lingkungan berwujud permukiman tradisional sebagai respon sifat lingkungannya. Permukiman tradisional masyarakat Indonesia ditinjau dari segi historis banyak berada di daerah aliran sungai karena akses transportasi. Akses daerah aliran sungai merupakan karakteristik permukiman awal sebagai cikal bakal tumbuh dan berkembangnya suatu kota, selaras dengan lingkungan sosial masyarakat Indonesia.

Kalimantan Tengah adalah salah satu contoh kota di Indonesia yang memiliki banyak anak sungai dengan muaranya adalah sungai Kahayan. Tipologi mayoritas masyarakatnya bermukim dan menggantungkan hidup pada sungai. Sungai merupakan urat nadi perekonomian sebagai lahan mata pencaharian, sebagai tempat bermukim sekaligus sebagai prasarana transportasi masyarakat yang sangat besar pengaruhnya di dalam pola sosial dan budaya masyarakatnya, sehingga kota Palangkaraya dikenal dengan sebutan "Kota Air".

Sungai Kahayan memiliki lebar bantaran sungai 200m dengan karakteristik setting keunikan aktivitas keseharian penduduk yang tinggal di tepi sungai kebanyakan merupakan komunitas tepian sungai secara fisik bentuk permukiman berkembang organik dan akrab dengan alam. Permukiman tepian sungai Kahayan di Kota Palangkaraya adalah permukiman awal memiliki keunikan pola permukiman memanjang mengikuti bentuk sungai. Orientasi rumah menghadap ke sungai sebagai bagian dari lingkungan permukimannya dan sebagai tempat yang menarik untuk bermukim. Menurut Tjilik Riwut (1979) dalam Elbas (1986) Struktur hunian kawasan tepian Sungai Kahayan ini berada di atas sungai dengan karakteristik keunikan rumah terdiri: 1) rumah rakit (Raft House), 2) rumah tiang (Pillar House) dan 3) rumah beton (Permanent House).

Keunikan Daerah Aliran Sungai Kahayan ialah pola sirkulasi jalan yang terbentuk. Pola sirkulasi ini ditemui pada kawasan permukiman antara lain: Jalan titian kayu (wood bridge), Jalan tanah (unpavement) dan Jalan cor beton sebagai penghubung jalan kota dan pusat-pusat kegiatan ekonomi. Pola sirkulasi kawasan tepian sungai adalah organik membentuk pola sirkulasi linier/ sejajar (Linier pattern)seperti terlihat pada Gambar 1.yaitu perkembangan kota mengikuti sungai(alami) dan mempengaruhi perkembangan bentuk Kota Palangkaraya.

Bila dilihat dari perkembangan kawasan tepian sungai Kahayan ini memegang peran penting dalam upaya perkembangan transportasi sungai di masa mendatang mengingat posisinya berada di pusat Kota Palangkaraya. Oleh karena itu, penelitian yang menitik beratkan pada perencanaan transportasi sungai terhadap perkembangan pusat kota merupakan ide penelitian ini yaitu model pengembangan transportasi sungai dan merumuskan konsep pola sirkulasi kawasan tepian sungai yang unik dari kawasan kota tepian sungai merupakan salah satu upaya konservasi eko-wisata tepian sungai di masa 
mendatang. Sedangkan manfaat penelitian ialah sebagai upaya pengenalan model pengembangan transportasi sungai dan merekomendasikan modal pola sirkulasi kawasan tepian sungai yang unik sebagai wisata sungai. Model pola sirkulasi bermanfaat membuka akses menuju ke kawasan pelestarian arsitektur bangunan tua dan menuju wisata tepian sungai sebagai aset andalan eko-wisata Kota Palangkaraya di masa mendatang.

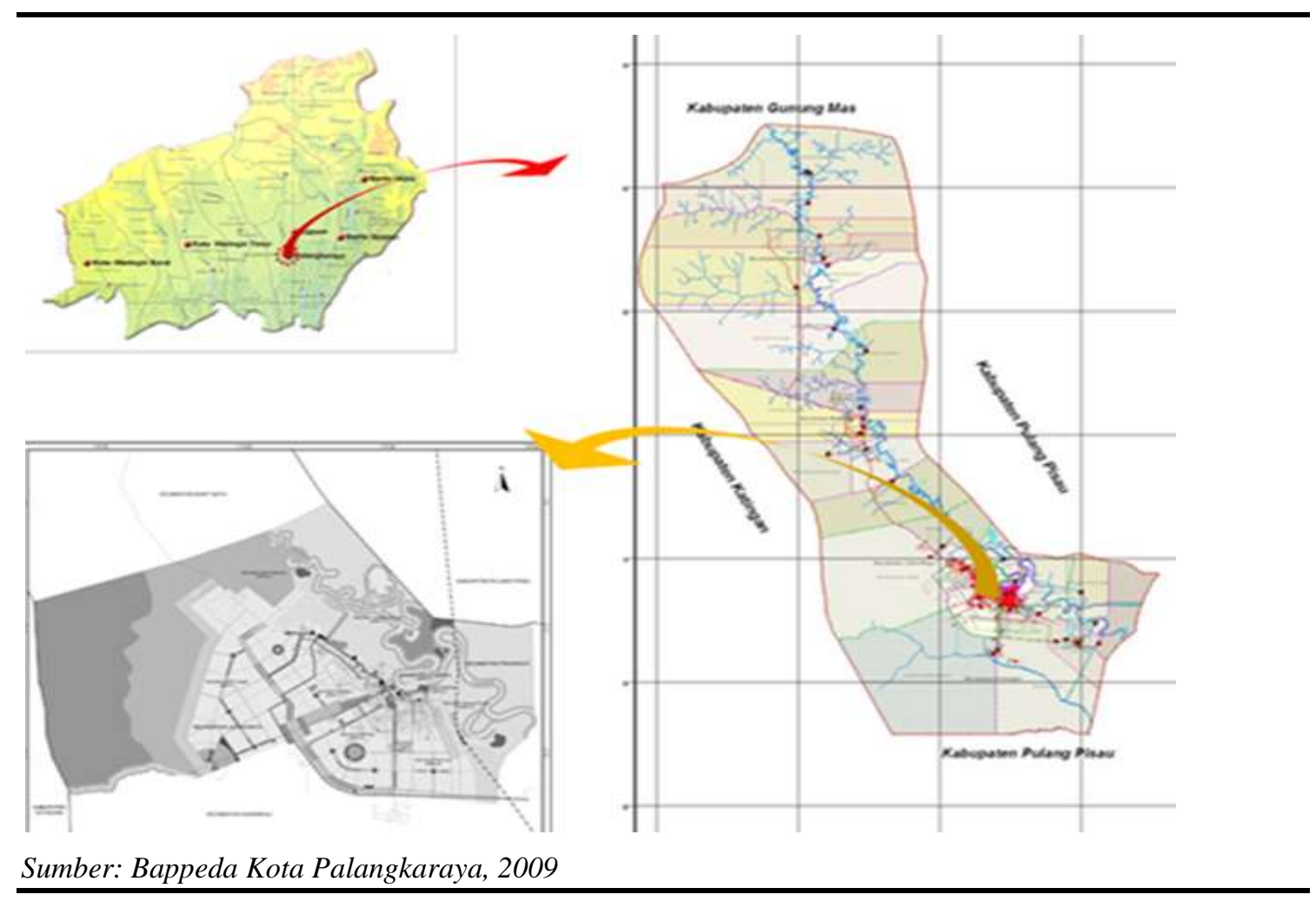

Gambar 1. Peta Kota Palangkaraya

\section{Model Pola Dan Struktur Kota Tepian Sungai}

Macam-macam pola dan struktur kota tepian sungai di Kalimantan (Budi Prayitno, 2005) pada Gambar 2 dijabarkan delapan macam, yaitu: (1) sungai membelah kota; (2) kota berada di pinggiran sungai; (3) kota dibelah oleh beberapa sungai dan anak sungai; (4) kota rawa; (5) sungai membelah kota pantai; (6) sungai membelah kota di ketinggian pegunungan; (7) sungai membelah kota danau; dan (8) kota pantai yang berdekatan dengan sungai. Karakteristik ini tentunya berbeda dengan satu dan lainnya. Selain pola permukiman, untuk morfologi kampung pedesaan di tepi air menurut Respati (1999 dalam Umar Lubis, 2009) membagi dua bagian pola permukiman, yaitu: (1) Kampung di pesisir pantai, pola permukiman terbentuk karena adanya potensi dan kendala lingkungan. Pantai landai dengan ombak tenang akan lebih dominan dipakai sebagai lokasi hunian dibanding dengan pantai curam. Struktur fisik lingkungan dominan berperan sebagai lokasi; (2) Kampung di sepanjang sungai. 


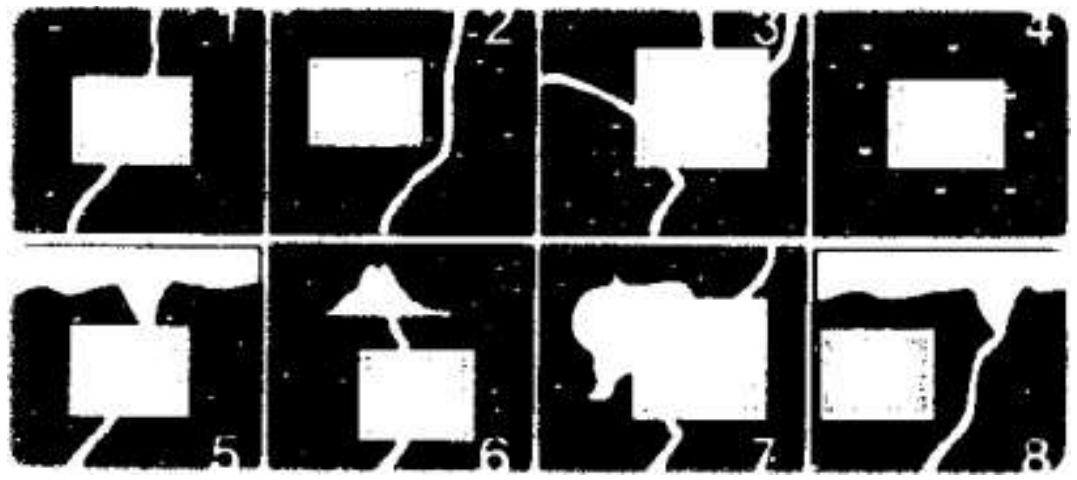

Sumber: Prayitno, 2004

Gambar 2. Struktur dan Pola Kota Tepian Sungai Kalimantan

Karakteristik ini tentunya berbeda dengan satu dan lainnya. Selain pola permukiman, untuk morfologi kampung pedesaan di tepi air menurut Respati (1999 dalam Umar Lubis, 2009) membagi dua bagian pola permukiman (Tabel 2. Pola Permukiman Atas Air), yaitu:

(1) Kampung di pesisir pantai, pola permukiman terbentuk karena adanya potensi dan kendala lingkungan. Pantai landai dengan ombak tenang akan lebih dominan dipakai sebagai lokasi hunian dibanding dengan pantai curam. Struktur fisik lingkungan dominan berperan sebagai lokasi;

(2) Kampung di sepanjang sungai. Pola perkampungan di sepanjang sungai di pedesaan menggunakan sungai sebagai sarana transportasi, mempunyai kecenderungan pola yang linier dengan orientasi mengikuti pola aliran sungai.

Tabel 1. Pola Permukiman Atas Air

\begin{tabular}{|c|c|c|}
\hline No & Pola Permukiman Tradisional di atas Air & $\begin{array}{l}\text { Pola Permukiman Non Tradisional (Urban) di atas } \\
\text { Air }\end{array}$ \\
\hline 1 & $\begin{array}{l}\text { Pola bentuk dan ruang serta } \\
\text { bangunan/rumah ialah heterogenitas }\end{array}$ & $\begin{array}{l}\text { Pola bentuk dan ruang serta fungsi bangunan/rumah } \\
\text { ialah homogenitas }\end{array}$ \\
\hline 2 & $\begin{array}{l}\text { Adanya nilai-nilai tradisi tertentu yang dianut } \\
\text { berkaitan dengan huniannya, seperti orientasi, } \\
\text { ornamentasi, konstruksi dan lain-lain }\end{array}$ & $\begin{array}{l}\text { Tidak ada nilai-nilai tradisi tertentu yang dianut } \\
\text { dengan huniannya. Arsitektural bangunan dibuat } \\
\text { dengan kaidah tradisional maupun modern, sesuai } \\
\text { dengan latar belakang budaya dan suku masing- } \\
\text { masing. Segala hal didasarkan atas kepraktisan dan } \\
\text { kemudahan }\end{array}$ \\
\hline 3 & $\begin{array}{l}\text { Pola persebaran perumahannya cenderung } \\
\text { membentuk suatu cluster berdasarkan } \\
\text { kedekatan keluarga atau kekerabatan }\end{array}$ & $\begin{array}{l}\text { Pola persebaran perumahannya cenderung } \\
\text { menyebar dan linier atau membentuk suatu cluster } \\
\text { yang lebih didasarkan atas pertimbangan ekonomis, } \\
\text { seperti kedekatan dengan pelabuhan, pasar } \\
\text { terapung, dan lain-lain }\end{array}$ \\
\hline
\end{tabular}

Sumber: Respati (1999 dalam Umar Lubis, 2009)

\section{Peranan Sungai Kahayan}

Tipologi masyarakat Kalimantan Tengah adalah menggantungkan hidupnya kepada sungai. Sungai merupakan urat nadi perekonomian masyarakat yang mempengaruhi pola kehidupan, yaitu menempatkan sungai sebagai lahan mata pencaharian sekaligus prasarana transportasi (Riwut, 1979). Moda transportasi awal yang digunakan penduduk adalah perahu, kelotok dan kapal niaga. Sebagai moda transportasi, sungai-sungai di Kalimantan 
Tengah yang mengalir dari utara ke selatan, sangat membantu transportasi masyarakat melalui sungai dari bagian hulu (utara) ke bagian hilir (selatan). Pada bagian hilir ini terdapat paling banyak permukiman masyarakat perkotaan hingga ke arah Kalimantan Selatan. Namun kondisi ini mengakibatkan pembangunan prasarana jalan darat, yang membujur dari timur ke barat menjadi mahal karena harus dibangun beberapa buah jembatan bentang panjang.

Berdasarkan data Dinas Pekerjaan Umum Provinsi Kalimantan Tengah tahun 2006 bahwa di Provinsi Kalimantan Tengah terdapat 11 sungai besar dan puluhan sungai kecil (cabang sungai) lainnya yang dapat dimanfaatkan sebagai prasarana transportasi. Sungaisungai utama di Kalimantan Tengah adalah Sungai Jelai, Arut, Kumai, Lamandau, Mentaya, Katingan, Kahayan, Kapuas, Barito dan Sebangau. Sungai-sungai tersebut bermuara di Laut Jawa dengan panjang hingga mencapai $900 \mathrm{~km}$ dengan panjang terlayari mencapai 720 $\mathrm{km}$. Selain sungai-sungai tersebut di atas, terdapat beberapa anjir (sungai buatan) yang kedudukannya cukup penting dalam sistem transportasi, yaitu: Anjir Kalampan, Anjir Basarang, Anjir Serapat, Anjir Tamban, Anjir Baturaya, Anjir Terusan, Anjir Nusa dan Anjir Simpur.

Keberadaan sungai-sungai di Provinsi Kalimantan Tengah. sebagai prasarana transportasi sangat dipengaruhi oleh musim, terutama musim kemarau. Pada musim kemarau kondisi kedalaman beberapa sungai tidak memungkinkan untuk dilayari sampai ke hulu, sehingga tingkat aksesibilitas berkurang, dan hanya setengah panjang sungai yang dapat dilayari. Pemanfaatan sungai-sungai di Kalimantan Tengah sebagai prasarana angkutan sungai relatif sangat terbatas, terutama berkaitan dengan kedalaman/tinggi muka aimya. Dengan kata lain bahwa pemanfaatannya relatif dimungkinkan pada saat muka air naik, yaitu pada waktu musim hujan dengan armada kapal motor besar, sementara pada musim kemarau, kondisi sungai di Kalimantan Tengah hanya dapat dilayari menggunakan armada kapal yang berukuran kecil seperti terlihat pada Gambar 3.

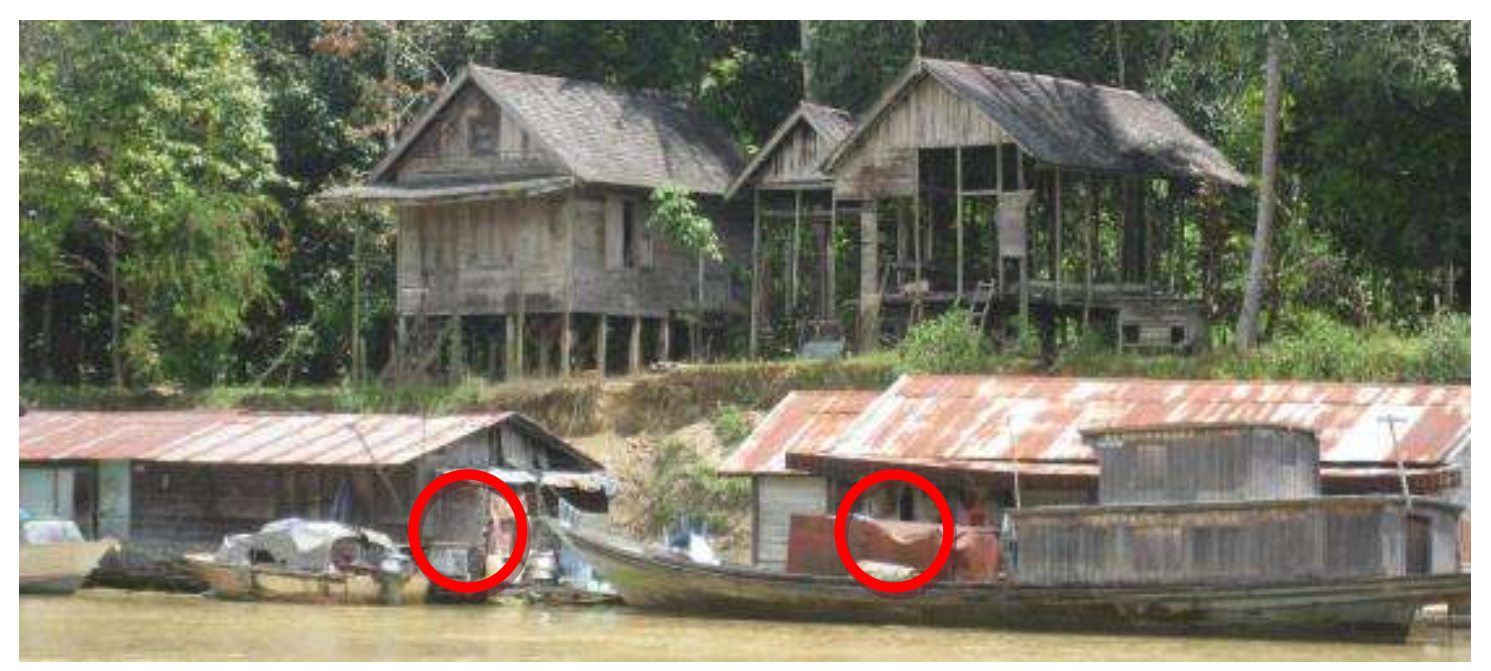

Sumber : Dokumentasi Pribadi, 2012

Gambar 3. Perahu atau Kelotok sebagai salah satu Moda Transportasi Sungai

\section{Potensi Pengembangan Transportasi Sungai}

Berdasarkan Peraturan Daerah Nomor 8 Tahun 2003 total luas wilayah Kalimantan Tengah adalah $153,567 \mathrm{~km}^{2}(15.356 .700 \mathrm{Ha})$ atau 1,5 kali luas pulau Jawa dengan jumlah 
penduduk 1.935.669 (hampir 2 juta jiwa) atau 553.057 Kepala Keluarga. Perbandingan luas wilayah dengan jumlah penduduk adalah 12 jiwa $/ \mathrm{km}^{2}$. Kemudian sesuai dengan UndangUndang Nomor 5 Tahun 2002 Provinsi Kalimantan Tengah memiliki 13 kabupaten dan 1 kota, 95 kecamatan, 123 kelurahan, 1.183 desa dan 66 buah kedemangan. Dari ke 13 kabupaten tersebut, 7 kabupaten sebagian wilayahnya bersentuhan dengan pesisir laut Jawa, sedangkan 6 kabupaten lainnya dan 1 kota berada di daerah dataran rendah, namun sedikit berbukit serta dilalui oleh aliran sungai-sungai besar Sungai Barito, Sungai Kahayan, Sungai Kapuas, Sungai Mentaya, Sungai Arut, Sungai Lamandau, dan lain-lain.

Daerah Aliran Sungai (DAS) dalam istilah asing disebut catchmen area, river basin, atau watershed. DAS ialah suatu wilayah daratan secara topografi dibatasi oleh punggungpunggung bukit yang menampung dan menyimpan air hujan untuk kemudian menyalurkan hujan yang jatuh diatasnya baik dalam bentuk aliran permukaan, aliran bawah permukaan, aliran bawah tanah ke sungai dan akhirnya bermuara ke danau atau laut. Wilayah daratan tersebut dinamakan Daerah Tangkapan Air (DAT/ Catchmen area) yang merupakan suatu ekosistem dengan unsur utamanya terdiri atas sumberdaya alam (tanah, air, dan vegetasi) dan sumberdaya manusia sebagai pemanfaat sumberdaya alam. (Asdak. C, 2007, Hidrologi dan Pengelolaan DAS , Gadjahmada University Press, Yogyakarta)

Daerah Aliran Sungai ini terlihat pada Gambar 4. Banyak didominasi oleh etnis Melayu (Banjar, Bugis, dan Madura) dikenal sebagai masyarakat pesisir yang berprofesi sebagai nelayan. Sedangkan di daerah pedalaman dan hulu-hulu sungai didominasi oleh etnis Dayak yang berprofesi sebagai petani peladang berpindah dan perambah hutan. Hutan tropis dengan luas 134,937,25 atau mencapai 87,87\% dari luas wilayah Kalimantan Tengah sangat dikenal sebagai penghasil kayu. Hutan inilah yang menjadi sumber kehidupan bagi warga masyarakat yang tinggal di daerah pedalaman. kelompok masyarakat yang tinggal di daerah pesisir relatif lebih mudah dijangkau bila dibandingkan dengan kelompok masyarakat yang tinggal di daerah pedalaman dan hulu-hulu sungai.

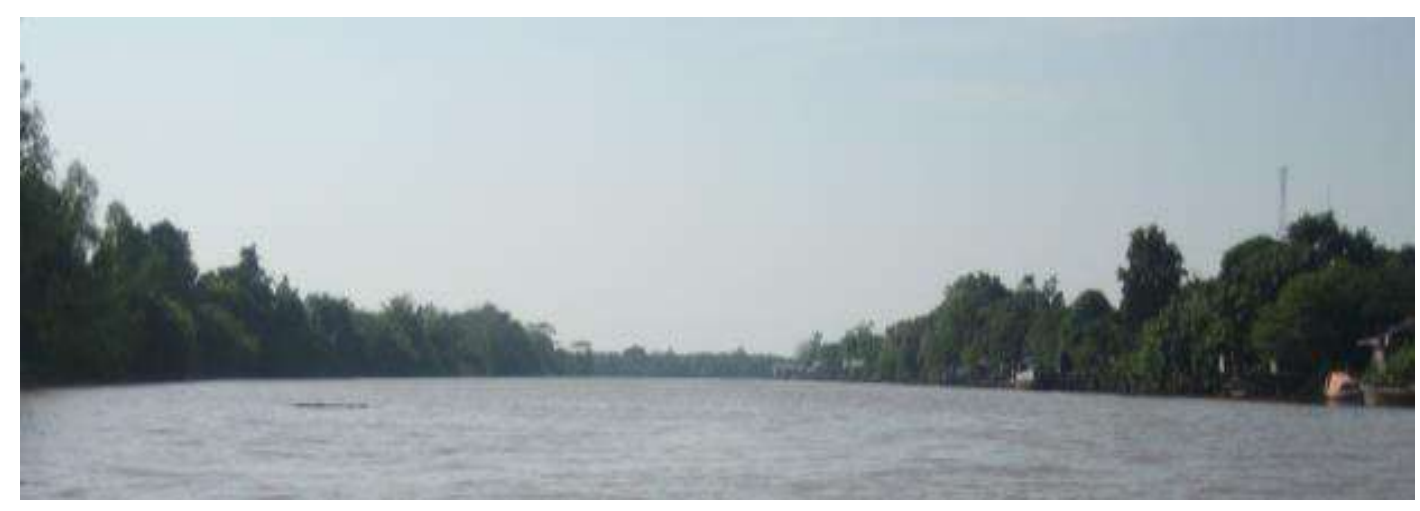

Sumber : Dokumentasi Pribadi, tahun 2012

Gambar 4. Pengembangan Potensi Transportasi Sungai Kahayan

\section{Pola Permukiman Di Kawasan Tepian Sungai}

Awal mula sejarah Kota Palangka Raya adalah berawal dari permukiman di sekitar kawasan Tepian Sungai Kahayan (Salilah, 1977). Orientasi masyarakat Dayak Ngaju yang hidup di bantaran sungai Kahayan ini memiliki orientasi rumah menghadap ke sungai. Menurut tulisanHans Scharer(1963), dalam The Conception of God Among A South Borneo People menyatakan bahwa masyarakat Dayak Ngaju sebagai suku asli terbesar yang bermukim di sepanjang bantaran Sungai Kahayan menganut falsafah hidup sungai sebagai 
sumber kehidupan, melakukan aktivitas sosial dan perdagangan dengan memanfaatkan jalur transportasi air. Fungsi Sungai sebagai falsafah masyarakat Dayak Ngaju yaitu konsep orientasi tempat tinggal menghadap ke sungai, dimana Sungai sebagai sumber kehidupan (KMA Usop, 1993), ini diperkuat juga di tulisan Damang Yohanes Salilah (1977) dalam bukunya Teknologi Dayak Ngaju, menyertakan salah satu bangunan yang dikenalinya yaitu Pasah Mandulangdi kawasan tepian Sungai Kahayan berfungsi sebagai tempat tinggal bagi para pendulang selama mereka bekerja. Hal ini membuktikan bahwa sungai merupakan orientasi, tempat tinggal dan tempat bekerja bagimasyarakat Dayak.Oleh karena itu, maka dirasakan kurang tepat bilamana kita meninggalkan konsepsi hidup masyarakat Dayak Ngaju tepian Sungai Kahayan, peran sungai sebagai orientasi, tempat tinggal dan mengembangkankehidupan manusia. Menurut Koentjaraningrat (1971) Masyarakat Kalimantan hidup ditepian-tepian sepanjang sungai, terutama sungai besar. Rumah hunian biasanya sejajar atau tegak lurus dengan sungai dan didirikan diatas tonggak-tonggak kayu.Struktur kawasan tepian Sungai Kahayan ini merupakan struktur hunian yang berhubungan langsung dengan sungai dan tempat bermukim.

Sejarah kawasan permukiman tepian Sungai Kahayan telah ada sejak abad ke-18, sebelum dicanangkannya Palangkaraya menjadi ibukota Kalimantan Tengah. "Kampung Pahandut" yaitu nama kawasan permukiman tepian Sungai Kahayan mempunyai makna berkaitan dengan kawasan ini. Kampung Pahandut berasal dari kata Bapa Handut, artinya ayah Handut. Bapa Handut adalah salah satu penduduk yang membuka hutan belantara untuk dijadikan tempat tinggal sementara yang kini bernama Kampung Pahandut. Di dalam Kampung Pahandut ini dibangun dermaga pelabuhan Rambang dan disebelah barat daya Kampung Pahandut ini terdapat danau yang bernama Danau Seha, namun seiring dengan berkembangnya kawasan permukiman danau ini pun menghilang (tidak berair lagi). Pada Gambar 5 merupakan permukiman awal di Kampung Pahandut menurut catatan notulen rapat Damai Suku Dayak Tumbang Anoi di tahun 1894 awalnya sekitar delapan buah rumah panjang (Betang/rumah adat Suku Dayak), satu rumah dihuni oleh 5 keluarga, diperkirakan jumlah penduduk waktu itu ialah 40 keluarga dan seluruhnya menghadap ke sungai Kahayan (Pemda Kota Palangkaraya, 2003: 20). Pada tahun 1957 di Kawasan Kampung Pahandut ini terdapat sekitar 21 rumah dengan jumlah penduduk sekitar 250 jiwa (KMA. Usop, 1996, dalam Wijanarka 2001).

Pada awalnya kawasan tepian sungai Kahayanini merupakan embrio awal tumbuh dan berkembangnya Kota Palangka Raya. Lokasi kawasan permukiman ini di tepian Sungai Kahayan yaitu Kampung Pahandut, Kelurahan Pahandut, Kecamatan Pahandut, Kota Palangkaraya (Gambar 5.) merupakan permukiman awal masyarakat Palangkaraya. Sejarah kawasan permukiman tepian sungai ini tercatat di laporan Zacharias Hartman, seorang pejabat Pemerintah Hindia Belanda, melakukan perjalanan menyusuri Sungai Kahayan dan Sungai Kapuas Bulan Oktober 1823 termuat dalam Buku Sejarah Kota Palangkaraya (Pemda Kota Palangkaraya, 2003: 20). Keunikan karakteristik setting geografis dan pilihan lokasi merupakan alasan utama para pemukim "Kampung Pahandut" mendekati sumber air bagi kegiatan sehari-hari dan sebagai kemudahan transportasi sungai, dimana masyarakat masih bergantung dengan alam. Sungai merupakan urat nadi perekonomian sebagai lahan mata pencaharian, sebagai tempat bermukim sekaligus sebagai prasarana transportasi masyarakat yang sangat besar pengaruhnya di dalam pola sosial dan budaya masyarakatnya, sehingga kota Palangkaraya dikenal dengan "Kota Air". (RUTRK Kota Palangka Raya 1999-2009).

Ciri unik rumah tinggal seperti pada Gambar 6. berupa rumah Lanting (Raft House) dan pada Gambar 7. rumah panggung (Pillar House) sebagai tipologi bangunan yang kaya dengan desain arsitektur lokal. Dalam tahap perkembangannya tingkat kepadatan hunian tertinggi adalah rumah rakit (Raft House) dan rumah tiang (Pillar House) di kawasan tepian sungai ini dihuni masyarakat asli dan pendatang sebagai tempat tinggal dan tempat untuk 
memenuhi kebutuhan hidup dengan mata pencaharian nelayan dan pembuat perahu (Tjilik Riwut, 1979).
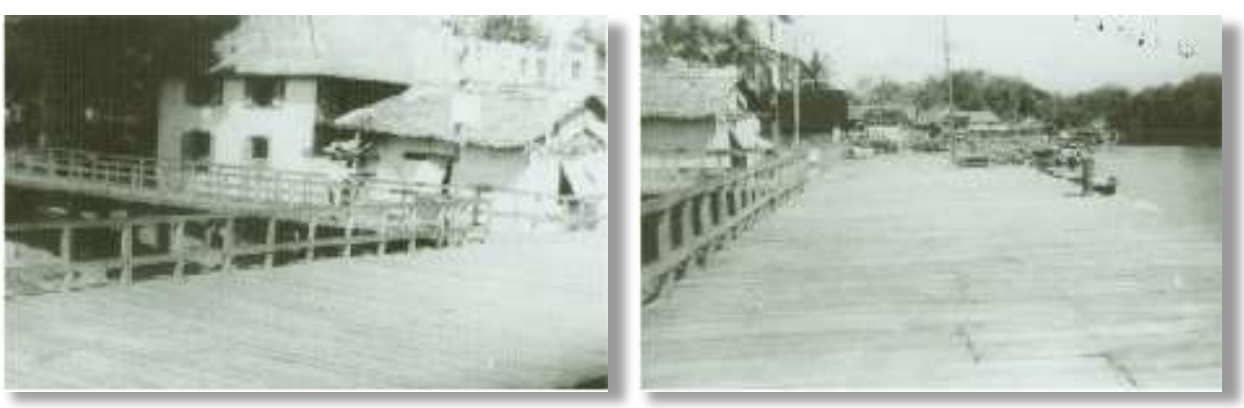

Sumber : Pemerintah Kota Palangka Raya. Sejarah Kota Palangka Raya. 2003. Hal 62

\section{Gambar 5. Kampung Pahandut Tempo Dulu dan dermaga Rambang}
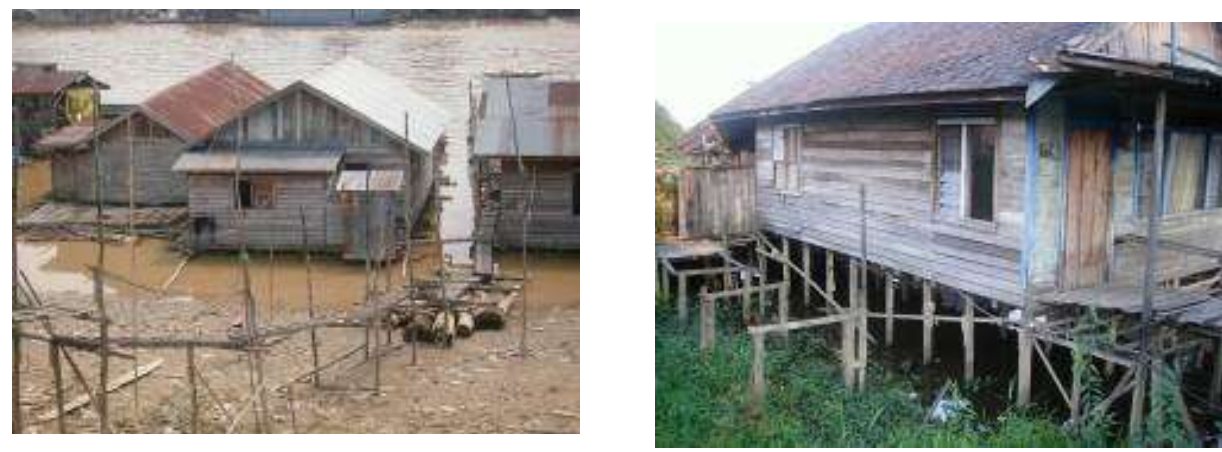

Sumber:Dokumentasi Pribadi, 2011

\section{Gambar 6. Rumah Lanting (kiri) dan Rumah Tiang (kanan)}

\section{Metode Penelitian}

Tujuan penelitian ini adalah menggali potensi pola sirkulasi tepian Sungai Kahayan (gambar 3) dan mengembangkan konsep pola sirkulasi sebagai elemen pembentuk kota yang memiliki nilai historis kawasan yaitu kehidupan dan aksesibilitas permukiman tepian sungai. Metode penelitian ini menggunakan metode penelitian ekplorasi kualitatif lapangan (A qualitative Exploratory Research) berdasarkan ekplorasi data lapangan (field observation) nilai historis kawasan melalui survei, wawancara dan identifikasi potensi kawasan tepian Sungai Kahayan. Kawasan yang menjadi kasus penelitian adalah potensi transportasi sungai dan pola sirkulasi tepian sungai Kahayan Kota Palangkaraya. Data-data dikumpulkan melalui literature review dan pengamatan lapangan (field observation) atas aspek fisik lingkungan buatan yang mendukung potensi transportasi sungai antara lain: sarana transportasi sungai (jalan, titian, jembatan), dermaga dan pelabuhan serta rumah tinggal. Selanjutnya data dianalisis dengan metode komparasi dan deskriptif-interpretatif dengan berbagai aspek kehidupan.

\section{Lokasi Penelitian}

Penelitian ini mengambil lokasi pada kawasan permukiman informal tepian sungai Kahayan Provinsi Kalimantan Tengah. Sungai Kahayan adalah Kawasan tepian sungai 
Panjang $100 \mathrm{~km}$ dan lebar 200m. Luas Wilayah administratif Kota Palangka Raya $2.400 \mathrm{~km}^{2}$ lahan terbangun $\pm 226,67 \mathrm{~km}^{2}$ dengan jumlah penduduk \pm 210.600 jiwa (56.000 KK). Batas administrasi wilayah meliputi: 1) Utara: Kabupaten Gunung Mas; 2) Selatan: Kabupaten Pulang Pisau; 3) Timur: Kab. Gunung Mas; dan 4) Barat: Kabupaten Katingan.

Kajian empirik kawasan permukiman informal ini berada sepanjang tepian sungai Kahayan dalam lingkup Kota Palangkaraya. Lokasi penelitian adalah pada tingkat Kelurahan akan diambil sampel model per Rukun Warga/RW sebagai sampel pola sirkulasi kawasan.

Sungai Kahayan merupakan sungai besar yang awal mulanya merupakan jalur transportasi antar kota maupun daerah di Kalimantan Tengah. Hingga saat ini, sungai tersebut masih berfungsi sebagai penghubung ke daerah-daerah pedalaman yang belum terjangkau jalur jalan darat. Sungai-sungai di Kalimantan Tengah termasuk Sungai Kahayan merupakan sarana transportasi yang dominan dan sungai sebagai urat nadi perekonomian daerah. Kawasan Bantaran Sungai Kahayan ini pada musim tertentu seperti pada musim hujan akan terlihat seolah-olah berdiri diatas air (terapung). Akan Tetapi, bila pada musim kemarau, kawasan permukiman ini akan terlihat berdiri di atas daratan. Kondisi eksisting ini merupakan keunikan yang terdapat di kawasan selain pola permukiman juga pola sirkulasi yang berbeda karena pada kawasan ini terdapat Jalan titian kayu (wood bridge), Jalan tanah (unpavement) dan Jalan cor beton memiliki variasi lebar $2-3$ meter(Garib dan Hamidah, 2011).Berikut Peta wilayah administrasi Provinsi Kalimantan Tengah dapat dilihat pada Gambar 8.

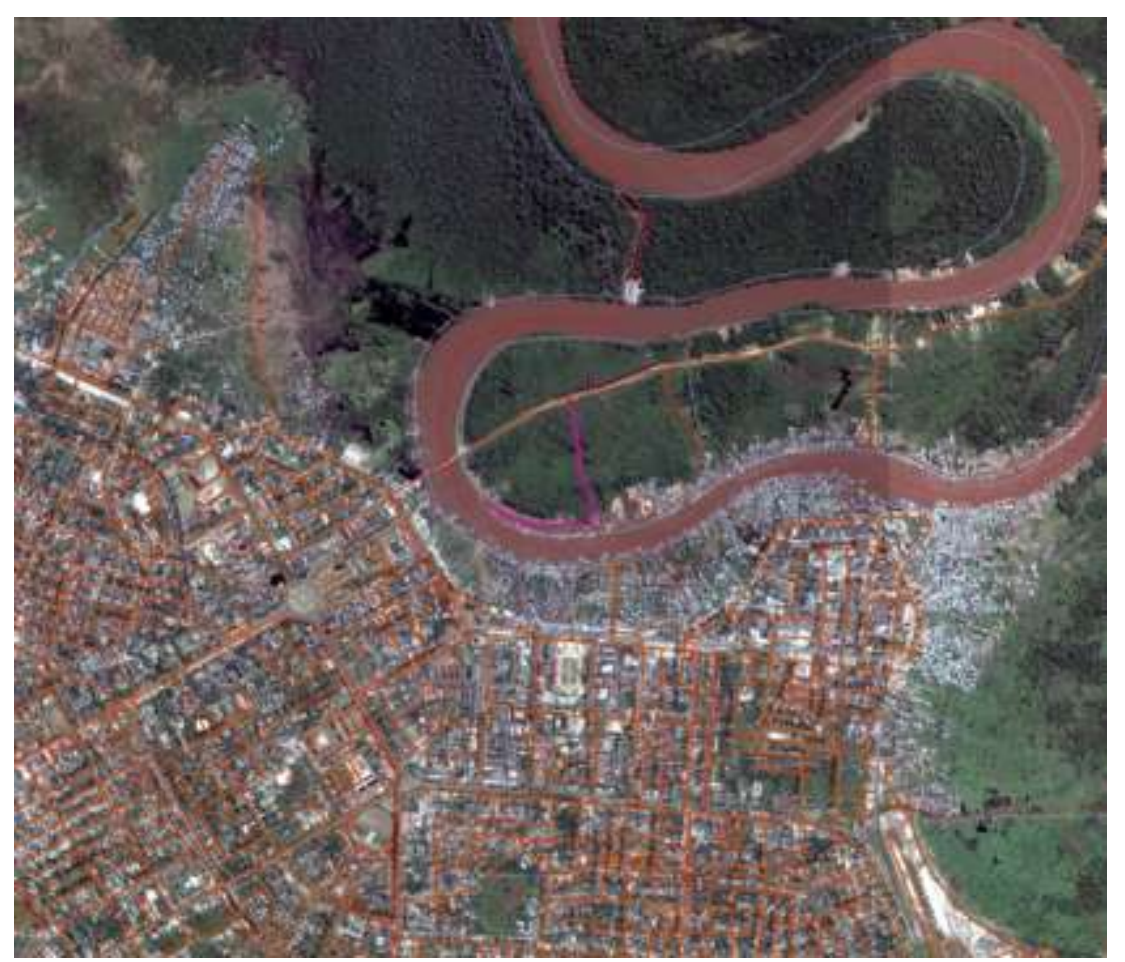

Sumber: BAPPEDA Kota Palangkaraya, 2012

Gambar 8. Peta Sungai Kahayan Kota Palangkaraya 


\section{Tempat Dan Waktu Penelitian}

Lokasi penelitian berada di Kelurahan Pahandut, Kota Palangkaraya. Pola sirkulasi fokus pada penggal Jalan Ahmad Yani, penggal Jalan Dr. Murjani, dan penggal Jalan Sulawesi sebagai bagian Kawasan Daerah Aliran Sungai (DAS) Kahayan yang merupakan kawasan percepatan pengembangan wilayah perkotaan di Palangka Raya. Kawasan ini memiliki akses utama ke berbagai kabupaten lain seperti Kabupaten Barito Selatan, Kabupaten Katingan, dan Kabupaten lainnya yang berada di wilayah Propinsi Kalimantan Tengah. Selain itu kondisi alam dan lingkungannya dominan kawasan hijau yang masih murni, sehingga penataan pola sirkulasi dan penataan ruang hijau tetap terpelihara lingkungannya, dapat direncanakan dan dikontrol dengan mudah keberadaan ruang hijau kawasan ini.

\section{Tahapan Kegiatan Penelitian}

Tahapan kegiatan penelitian akan dibagi dalam 3 tahapan kegiatan kegiatan pengumpulan informasi dan data lapangan di tahun I dan kegiatan analisa serta pendekatan konsep berdasarkan model perencanaan pola sirkulasi kawasan tepian sungai akan dilakukan pada tahun II. Berdasarkan lingkup penelitian pada Gambar 9, maka kegiatan penelitian dibagi dalam tiga tahap, yaitu:

1. Pada Tahap I adalah kegiatan awal yaitu sketsa lapangan/ pemetaan manual kawasan tepian melalui obsevasi lapangan dan wawancara mendalam dengan responden yaitu penduduk tepian sungai Kahayan sebagai narasumber yang mengetahui pola sirkulasi dan bentuk hunian di kawasan tepian sungai Kahayan.

2. Pada Tahap II akan dilakukan kegiatan analisa berdasarkan proses data observasi lapangan dan wawancara dengan responden penduduk tepian sungai Kahayan. Data diolah melalui model data spasial dari peta manual menjadi data digital dengan pembuatan peta digital menggunakan program komputer GIS kawasan tepian sungai untuk melihat perkembangan pola sirkulasi dan bentuk hunian lebih akurat dan detail.

3. Pada Tahap III akan dilakukan teknik ujicoba dan pemodelan pola sirkulasi dan bentuk hunian untuk pengenalan konsep desain pola sirkulasi dan permukiman kawasan bersejarah kota dalam perkembangan Kota Palangkaraya.

\begin{tabular}{|c|c|c|}
\hline $\begin{array}{l}\text { TAHAP I. PERSIAPAN } \\
\text { PENELITIAN }\end{array}$ & $\begin{array}{l}\text { TAHAP II. ANALISA DATA } \\
\text { PENELITIAN }\end{array}$ & TAHAP III. PENGUJIAN \\
\hline 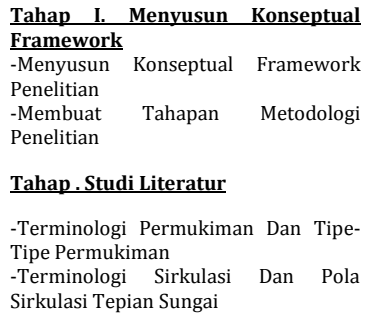 & $\begin{array}{l}\text { Tahap II. Analisa Data } \\
\text { Analisa Alt. Kajian Pola Sirkulasi Di Sekitar } \\
\text { Kawasan Tepian Sungai } \\
\text { 1. Tanah } \\
\text { 2. Bangunan } \\
\text { 3. Sirkulasi } \\
\text { 4. Sarana-Prasarana } \\
\text { Peta Digital Gis - Arc View: } \\
\text { Analisa Fisik Hunian Dan Pola Sirkulasi Di } \\
\text { Permukiman Tepian Sungai }\end{array}$ & $\begin{array}{l}\text { Tahap Iv. Pengujian Dan Rekomendasi } \\
\text { Pengujian Dan Rekomendasi } \\
\text { Model Data Digital Spasial Pola Sirkulasi } \\
\text { Dan Bentuk Hunian Kawasan Tepian } \\
\text { Sungai Kahayan }\end{array}$ \\
\hline
\end{tabular}

Sumber: Analisa Tahapan Penelitian, 2013

Gambar 9. Tahapan Penelitian 


\section{Analisa Dan Pembahasan Model Pengembangan Transportasi Sungai}

Model berikut ini merupakan model infrastruktur pendukung transportasi sungai dalam rangka menghidupkan kembali kawasan tepian sungai. Berdasarkan data dari hasil pengamatan di lapangan, model pembentuk ialah infrastrukturpendukung di kawasan tepian sungai Kahayan ditemukan pada prasarana fisik kawasan yang digunakan oleh masyarakat antara lain:(Hamidah, 2013).

\section{Jembatan}

Jembatan adalah struktur konstruksi yang berfungsi untuk menghubungkan dua bagian jalan yang terputus karena adanya bentang alam yang tidak memungkinkan untuk dilewati seperti lembah yang dalam, alur sungai, saluran irigasi, dan lain sebagainya. Jembatan pada permukiman tepian sungai memiliki fungsi utama sebagai jalur penghubung antara jalan darat yang terpisahkan oleh jalur sungai. Sebagai salah satu aspek pembentuk pola sirkulasi, jembatan di tepian sungai memiliki beberapa karakter khas selain sebagai jalur penghubung. Karakter tersebut terlihat dari ragam bentuk jembatan (sebagian besar terbuat dari kayu ulin dan ciri ukiran khas pada jembatan). Karakter lainnya ialah ikatan yang kuat antara jembatan dengan aktifitas masyarakat seperti kebiasaan atraksi anak-anak yang terjun ke sungai dari jembatan yang tidak terlalu tinggi, terjadinya pasar tumpah di atas jembatan, dan aktivitas menikmati lalu lintas sungai dari atas jembatan.

Pada Gambar 10. Jembatan yang ada disekitar kawasan tepian sungai Kahayan sebagian besar berbahan kayu dengan konstruksi tiang dan balok ulin dan kayu galam. Jarak antara tiang disesuaikan tingginya sehingga perahu, speed boat atau kelotok masih bisa melewatinya. Namun terdapat juga beberapa jembatan yang sukar dilewati pada saat air pasang, hal ini disebabkan jarak yang tersedia antara batas air dengan kolong jembatan sangat kecil, apabila kebiasaan orang-orang yang suka duduk di atas atap perahu, maka semakin menambah kecil jarak yang tersedia untuk melewati jembatan ini.

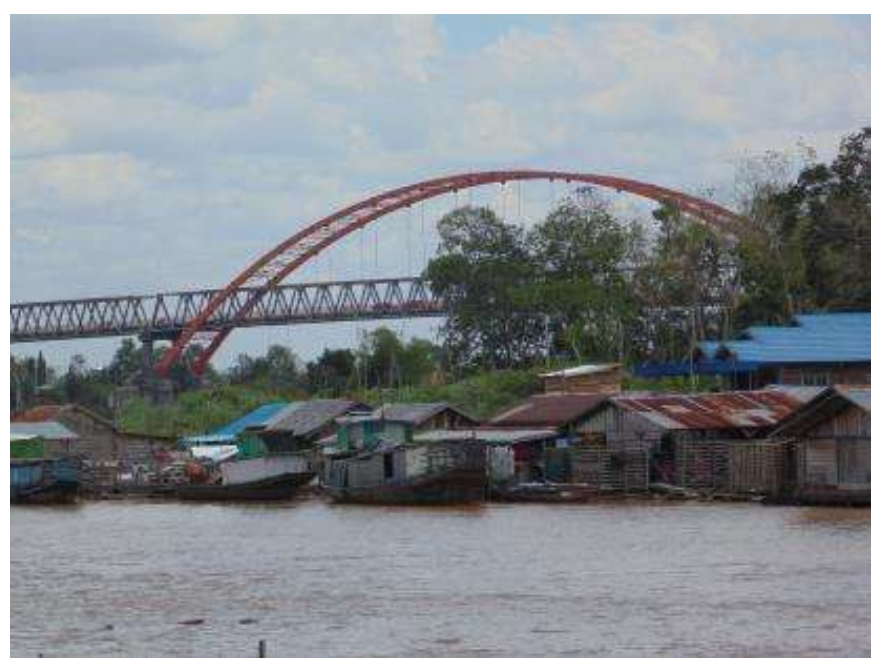

Sumber: Dokumentasi Pribadi, 2013

\section{Gambar 10. Jembatan Kahayan}

\section{Dermaga}

Secara umum pengertian dermaga ialah sarana tambatan bagi alat transportasi sungai/air (kapal, kelotok, jukung dan speed boat) bersandar untuk bongkar/muat barang atau embarkasi/debarkasi penumpang. Dermaga pada permukiman tepian sungai yang berukuran besar biasanya dibangun dengan kosntruksi panggung. Dermaga jenis ini dilengkapi dengan ruang tunggu bagi pengantar dan penjemput serta tersedia fasilitas 
kantin dan KM/WC. Material yang digunakan sebagian besar menggunakan kayu (lantai/dinding/rangka), ataupun variasi dengan beton (lantai beton, dinding kayu, dan struktur rangka kombinasi beton dan kayu).

Dermaga besar yaitu Dermaga Rambang (Gambar 11.) terdiri dari dua material dan konstruksi: (1) seluruhnya dengan konstruksi panggung; (2) sebagian menggunakan konstruksi panggung dan sebagiannya lagi menggunakan struktur rakit/lanting. Dermaga yang dibangun dengan konstruksi panggung menyediakan tangga-tangga bertiang untuk penumpang dari dan menuju area tambat kapal/perahu dan speed boat. Sedangkan dermaga yang dibangun dengan konstruksi tiang dan konstruksi rakit, menggunakan jembatan sebagai penghubung antara ruang tunggu pengantar maupun ruang kedatangan. Ruang-ruang yang berada dibagian berpanggung berfungsi untuk ruang pelayanan/administrasi, ruang tunggu, dan KM/WC ada juga yang menambahkan dengan fungsi kantin pada ruangan ini. Sedangkan ruang pada bagian struktur rakit biasanya digunakan sebagai ruang peralihan penumpang yang baru turun atau akan naik ke kapal, serta ruang untuk bertambatnya kapal.

Untuk dermaga yang berukuran kecil $(5 \times 5 m-6 \times 6 m)$ biasanya dibangun dengan konstruksi rakit (terapung). Kapal-kapal kecil yang datang bertambat langsung di bagian tepi dermaga. Pengantar dan penjemput bisa ikut turun ke dermaga, tetapi bisa juga menunggu di bagian darat dermaga. Untuk menuju dermaga rakit biasanya dihubungkan dengan titian kecil dari kayu yang bertumpu langsung ke balok kayu yang mengikat dermaga tersebut. Selain dua jenis dermaga ini terdapat juga dermaga-dermaga kecil yang menyatu dengan rumah penduduk. Pemilik rumah bisa langsung menambatkan kapal kecilnya (kelotok atau jukung) di bagian belakang rumah. Dermaga kecil ini biasanya bersifat privat dan bisa dianalogikan sebagai tempat parkir/garasi pada rumah-rumah di darat.

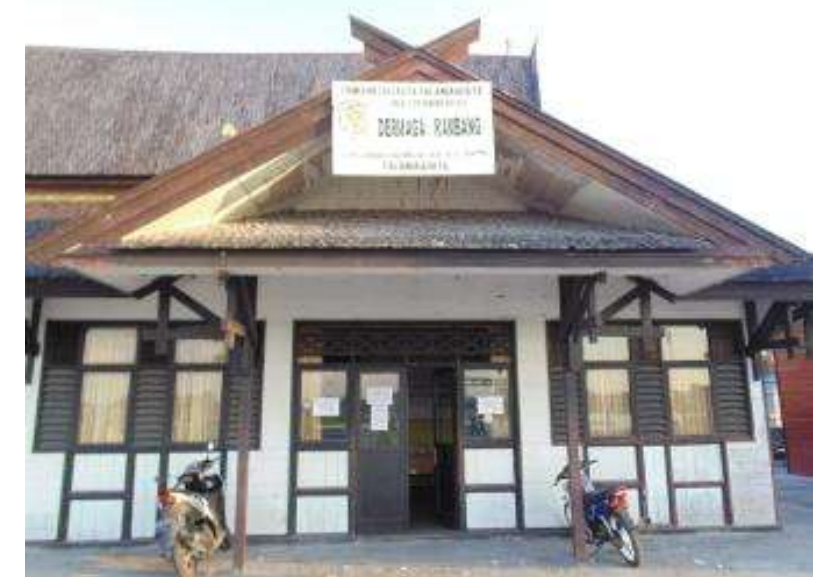

Sumber: Dokumentasi Pribadi, 2013

\section{Gambar11. Dermaga Rambang Kota Palangkaraya}

\section{Titian}

Titian ialah jalur sirkulasi penumpang yang digunakan masyarakat tepian sungai untuk mencapai rumah-rumah, menuju sungai ataupun sebagai jalur interaksi masyarakat di dalam kampung kawasan tepian sungai. Titian pada permukiman tepian sungai dibuat dengan konstruksi susunan papan ulin lebar sekitar 1-2 meter. Papan-papan ini dipasang 
berjajar menumpu pada tiang-tiang yang ditancapkan langsung ke sungai dengan tinggi tiang sekitar 1-3 meter.

Pada Tabel 2. terlihat dari pola titian pada permukiman tepian sungai dapat dibedakan menjadi tiga, yaitu: (1) titian lurus memanjang dengan posisi diapit barisan rumah atau jalur gang; (2) titian berada pada satu sisi saja, sedangkan sisi lainnya langsung jalur sungai; dan (3) titian bercabang-cabang dengan dimensi yang melebar pada setiap pertemuan cabang. Percabangan ini dianalogikan seperti persimpangan jalan dan mengikuti pola/lekuk sungai seperti pada perkampungan tepian sungai.

Pada beberapa kasus, terdapat titian-titian yang berukuran lebar biasanya digunakan masyarakat antara lain: (1) sebagai ruang publik untuk tempat berkumpul dan berinteraksi; (2) sebagai ruang bermain anak; (3) ruang olahraga/badminton; dan (4) pada saat-saat tertentu seperti kenduri atau rapat warga digunakan untuk ruang duduk/ruang rapat.

Jalan titian terbentuk akibat terbangunnya permukiman yang diikuti oleh jalan, dengan lebar 1,5 hingga 2 meter dengan material bahan lapisan kayu keras/ulin pada jalan utama maupun kayu sisa pada beberapa ruas jalan yang menghubungkan bangunan dan jalan utama. Jalan titian ini menghubungkan antara jalan utama dan rumah terapung (lanting, jamban, karamba), dengan material bahan lapisan kayu besi/ kayu ulin. Pada tabel 2 terlihat gambar panjang jalan titian mengikuti dari panjang jalur yang di lalui dari tepian atas ke tepian sungai. Ketinggian jalan titian utama dari permukaan tanah 1 hingga 3 meter, dengan jalan bagian luar sebagai patokan 0 meter. Kondisi jalan titian tidak sama di semua bagian. Jalan titian utama lebih bagus dan kokoh dari anak jalan titian. Jalan titian utama pembangunannya di fasilitasi oleh Pemerintah daerah. Anak jalan titian di bangunan dan bentuk dengan gotong royong di antara masyarakat dan ukurannya lebih bervariasi antara 0,6 hingga 1,5 meter (Hamidah, 2012).

Tabel 2. Spot Pola Jalan Titian

\begin{tabular}{|c|c|c|c|c|}
\hline Variabel & Pola linier & Pola menyebar & $\begin{array}{l}\text { Pola } \\
\text { Konvigurasi }\end{array}$ & Keterangan \\
\hline Spot 1 & $\begin{array}{l}\text { Jalan linier dari } \\
\text { bantaran ke sungai } \\
\text { Linier terhadap } \\
\text { kontur tepian sungai }\end{array}$ & \begin{tabular}{l}
\multicolumn{3}{l}{ Pola menyebar pada } \\
akhiir jalan ke \\
sungai
\end{tabular} & -- & $\begin{array}{l}\text { Pola menyebar } \\
\text { pada akhir titian }\end{array}$ \\
\hline Spot 2 & $\begin{array}{l}\text { Jalan linier dari } \\
\text { bantaran ke sungai }\end{array}$ & \begin{tabular}{lr}
\multicolumn{2}{l}{ menghubungkan } \\
antara titian & utama \\
dengan & jalan \\
terapung & menuju \\
lanting &
\end{tabular} & -- & $\begin{array}{l}\text { Linier sejajar dan } \\
\text { menghubungkan } \\
\text { antara titian } \\
\text { utama }\end{array}$ \\
\hline Spot 3 & $\begin{array}{l}\text { Jalan linier dari } \\
\text { bantaran ke sungai } \\
\text { Menghubungkan } \\
\text { jalan titian utama } \\
\text { dengan jalan ke } \\
\text { ruamah terapung }\end{array}$ & $\begin{array}{l}\text { menghubungkan } \\
\text { antara titian utama }\end{array}$ & $\begin{array}{l}\text { jalan } \\
\text { menghubungkan } \\
\text { jalan terapung } \\
\text { menuju lanting }\end{array}$ & $\begin{array}{l}\text { Linier sejajar dan } \\
\text { menghubungkan } \\
\text { antara titian } \\
\text { utama }\end{array}$ \\
\hline Spot 4 & $\begin{array}{l}\text { Jalan linier dari } \\
\text { bantaran ke sungai }\end{array}$ & -- & $\begin{array}{l}\text { Pola kombinasi } \\
\text { linier }\end{array}$ & $\begin{array}{l}\text { Konvigurasilinier } \\
\text { dan linier }\end{array}$ \\
\hline
\end{tabular}

Sumber : analisa hasil penelitian, 2013 
Akses utama yang menghubungkan kawasan adalah jalan titian. Pada Gambar 12 . Merupakan jalan titian yang menghubungkan antara tepian atas pada jalan A. Yani dengan sungai. Jalan titian ini merupakan jalan yang di gunakan oleh masyarakat yang menghubungkan antara bangunan dan bangunan, dan antara bangunan jalan titian utama.

Terdapat pula anak jalan titian yang menghubungkan antara jalan titian utama dengan bangunan. Konstruksi jalan titian utama ini terbuat dari kayu dengan lebar 1,5 - 2 meter, dan Panjang mengikuti dari panjang jalur yang di lalui dari tepian atas ke tepian sungai. Ketinggian jalan titian utama dari permukaan tanah 1 hingga 3 meter, dengan jalan bagian luar sebagai patokan 0 meter. Kondisi jalan titian tidak sama di semua bagian. Jalan titian utama lebih bagus dan kokoh dari anak jalan titian. Jalan titian utama pembangunannya di fasilitasi oleh Pemerintah daerah. Anak jalan titian di bangunan dan bentuk dengan gotong royong di antara masyarakat dan ukurannya lebih bervariasi.

Pola jalan pada kawasan yang cenderung sederhana atau mudah dalam pembagian blokblok bangunan adalah linier. Pola jalan utama dengan lebar jalan 2,5-5m membagi kawasan menjadi beberapa blok dan jalan-jalan kecil yang yang dibangun untuk akses kerumah dengan lebar 60-1,5m memberikan pola grid yang terlihat pada tampak atas permukiman yang terlihat padat.

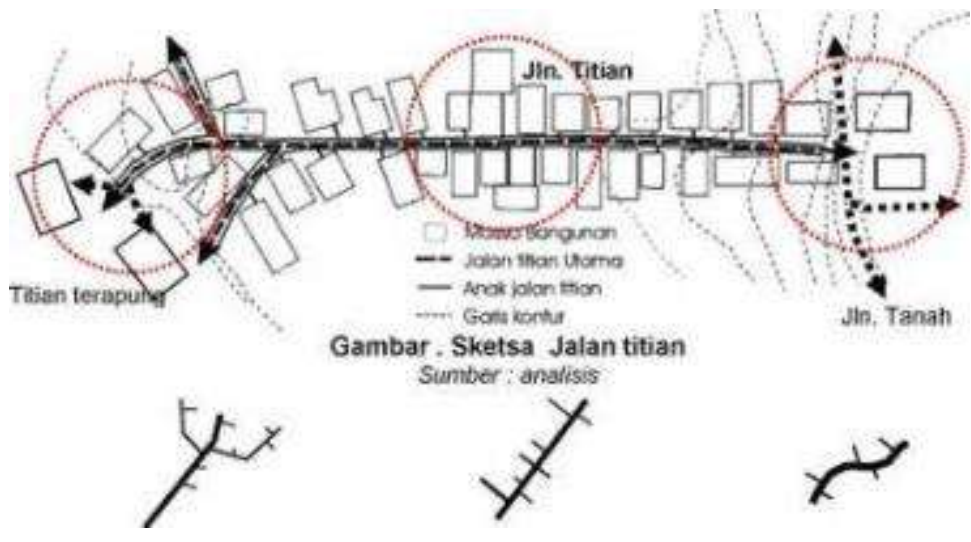

Pola menyebar

Pola Linier

Pola Linier Konfigurasi

Gambar 12. Ragam Pola Sirkulasi Pada Objek amatan (Sumber : analisa hasil penelitian, 2013)

\section{Rumah Lanting}

Rumah lanting ialah salah satu rumah tradisional Suku Dayak yang dibangun diatas air (Tjilik Riwut, 1979). Rumah-rumah lanting ini dapat dibedakan berdasarkan fungsinya, struktur pondasi dan konstruksi materialnya. Rumah lanting ditinjau dari fungsinya: (1) sebagai rumah; (2) sebagai usaha karamba ikan; (3) sebagai toko/warung;dan (4)sebagai tambatan jukung/perahu/kelotok. Berdasarkan sejarahnya, sebenarnya rumah lanting sudah digunakan sejak dulu sebagai tambatan jukung/perahu/kelotok, hal ini bisa dipahami karena pada waktu itu transportasi air merupakan transportasi utama di Kota Palangkaraya. Pada saat itu sungai sebagai orientasi tempat bertemu antara suku dan sampai saat ini fungsi rumah lanting tetap memiliki peranan sebagai tambatan perahu seperti terlihat pada Gambar 13. dan sekaligus usaha karamba. 


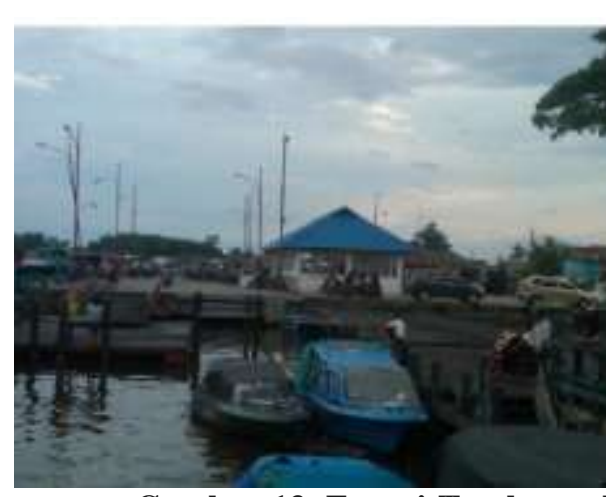

Gambar 13. Fungsi Tambatan Perahu

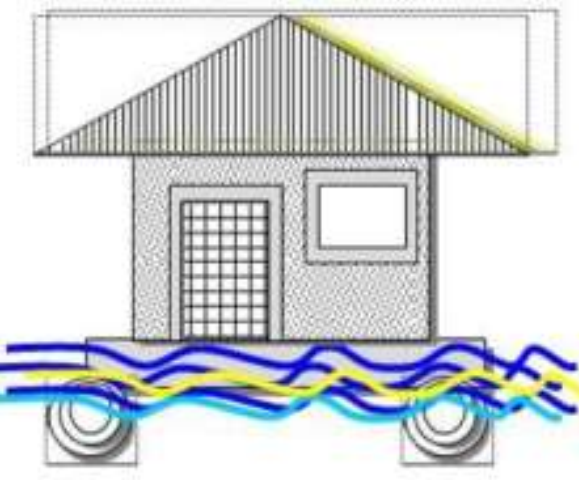

Gambar 14. Model Pondasi Rumah lanting

(Sumber : Dokumentasi Pribadi, 2013)(Sumber :

Analisa Hasil Penelitian, 2013)

Pada Gambar 14 terlihat pondasi pada rumah rumah lanting dibangun menumpu beban bangunan. Pada prinsipnya fungsi pondasi bangunan tradisional rumah lanting sebagai "alat pengapung" bagi bangunan. Hal ini disebabkan kondisi daya dukung tanah yang sangat lemah sebagai akibat tingginya kandungan air karena kondisi geografis lingkungan berada di tanah rawa (bangunan sebagian atau seluruhnya mengapung di atas air). Pada pondasi bangunan di atas rawa, maka yang menjadi media mengapung bangunan ialah rawa. Hal ini berbeda dengan pondasi pada bangunan modern yang umumnya beban bangunan disalurkan hingga ke bagian tanah keras atau mengandalkan daya geseran antara pondasi tiang dengan permukaan tanah.

Oleh karena itu Pondasi pada rumah lanting sangat mengandalkan pada kemampuan daya dukung dari material pondasi. Sebagaimana diketahui, khususnya pada masa-masa lalu di daerah ini memiliki potensi kayu yang sangat melimpah. Belajar dari alam masyarakat setempat menggunakan bahan kayu masih berbentuk hgelondongan/log) sebagai pondasi rumah lanting ini. Seiring semakin bertambahnya kebutuhan manusia akan kayu, semakin sulit mendapatkan kayu, maka masyarakat secara alamiah bertahan terhadap kondisi ini. Dalam perkembangannya masyarakat memilih bambu sebagai bahan pengganti kayu gelondongan tersebut. Bahan bambu masih didasarkan atas kemudahan mendapatkan bahan ini di lingkungan setempat.

Bahan bambu rumah lanting digunakan sebagai pondasi di Kota Palangkaraya didatangkan dari daerah hulu Barito (Buntok, Muara Teweh dan Puruk Cahu). Bambu-bambu ini dikirim ke Palangkaraya melalui transportasi sungai (perahu/kelotok). Bambu yang dijadikan pondasi umumnya dipasang dengan cara menyatukan beberapa bambu (biasanya antara 80-100 batang) menjadi satu dan di bagian ujungnya diikat menggunakan ban mobil bekas. Ban bekas dipilih memiliki sifat yang mudah didapat (limbah kendaraan), memiliki kekuatan dan kelenturan/elastis dan sifat karet yang tahan lama jika terendam air.

\section{Kesimpulan}

Berdasarkan hasil analisa dan pembahasan, beberapa hal dibawah ini perlu digaris bawahi sebagai kesimpulan :

1. Untuk mengenal wujud pola sirkulasi kawasan tepian Sungai Kahayan dan merekomendasikan model pengembangan transportasi sungai dan konsep pola sirkulasi kawasan tepian sungai yang unik sebagai model sirkulasi yang akan dikembangkan di kawasan wisata tepian sungai. Model pola sirkulasi bermanfaat membuka akses menuju ke kawasan pelestarian arsitektur bangunan tua tepian sungai sebagai aset andalan wisata Kota Palangkaraya di masa mendatang.

2. Berdasarkan hasil pengamatan penelitian terdapat empat aspek penting dalam pengembangan model transportasi sungai yang perlu diperhatikan, yaitu: (a) fungsi; (b) dermaga; (c) titian; dan (d) rumah lanting. 
3. Kajian aspek -aspek model pengembangan transportasi sungai dan kajian pola sirkulasi kawasan tepian sungai dapat dilihat dari tiga komponen, yaitu: (a) fungsi; (b) konstruksi; dan (c) material.

Faktor-faktor yang mempengaruhi model pengembangan transportasi sungai antara lain: (a) Faktor lingkungan lahan basah; dan (b) faktor budaya sungai. Faktor lingkungan lahan basah terlihat pada penggunaan konstruksi tiang/panggung dan konstruksi rumah rakit (terapung) untuk mengatasi kondisi lahan basah yang selalu tergenang air. Faktor budaya sungai terlihat pada kuatnya ketergantungan masyarakat dalam menggunakan sungai. Sungai berfungsi sebagai hunian/rumah lanting yang memiliki peranan, yaitu: (a) sebagai rumah; (b) sebagai usaha karamba ikan; (c) sebagai toko/warung;dan (d) sebagai tambatan jukung/perahu/kelotok.Saat ini fungsi rumah lanting tetap memiliki peranan sebagai tambatan perahu sekaligus usaha karamba.

4. Secara fisik faktor yang mempengaruhi keunikan pola bentuk sirkulasi pada permukiman kawasan tepian sungai Kahayan adalah: a) Kontur lahan pada tepian sungai; b) Ketinggian air sungai pada jalan titian dan jalan apung; c) Bangunan yang terbangun; d) Vegetasi; e) Kondisi lahan dengan beberapa anak sungai dan f) Kondisi sosial ekonomimasyarakat.

5. Berdasarkan hasil analisaterlihat bahwa keunikan pola sirkulasi tepian sungai sebagai konsep rekomendasi sirkulasi kawasan secara umum terdapat tiga pola kategori jalan:

a. Jalan tanah : Terbuat dari tanah, beton dan aspal; Lebar jalan antara $2-3$ meter; Posisi jalan antara bangunan, dan vegetasi; dan Pola jalan mengikuti kontur.

b. Jalan titian : Terbuat dari bahan kayu kelas I maupun kayu sisa; Lebar jalan antara 1 - 2,5 meter; Jalan titian datar menyesikan posisi lahan; Ketinggian jalan titian dari bantaran antara 1 - 3 meter ; pola jalan linier mengarah dari tepian sungai ke arah bantaran.

c. Jalan titian terapung : Terbuat dari bahan kayu kelas II maupun kayu sisa; Lebar jalan antara 0,6 - 1,5 meter; Jalan titian datar menyesuaikan posisi bangunan; Ketinggian jalan titian menyesuaikan ketinggian permukaan air sungai;

\section{Ucapan Terima Kasih}

Tulisan paper ini dapat selesai tepat pada waktunya karena bantuan berbagai pihak. Oleh karena itu penulis mengucapkan terima kasih dan penghargaan kepada Dekan Fakultas Geografi UGM, Program Studi Pasca Sarjana Geografi, UGM terima kasih atas kesempatan yang diberikan menimba ilmu. DIKTI sebagai pemberi beasiswa. Bapak Rektor Universitas Palangkaraya, Bapak Tatau Wijaya Garib, ST., MT., Bapak Ir. Syahrozi, MT., dan Ibu Tari Budayanti Usop, ST. MT. terima kasih atas diskusi yang telah dilakukan selama pelaksanaan penelitian ini.

\section{Daftar pustaka}

Aca Sugandhy. 2007. Prinsip Dasar Kebijakan Pembangunan Berkelanjutan Berwawasan Lingkungan, Penerbit Bumi Aksara

Asniawati. 2000. Pola spasial permukiman desa pantai, JUTA Pascasarjana UGM Yogyakarta Bambang Sugiyanto, 2005. Sungai dan Geneologi Budaya Banjar. Jurnal Kebudayaan KANDIL, edisi 7, tahun II Januasri 2005, Hal. 79-87. 
Barlow dan Newton. 1971, Meaning of Settlement, Hutchinson, London.

Damang Yohanes Salilah. 1977, Teknologi Dayak Ngaju "Pasah Mandulang"

Donovan, Michael. G. 2008. Informal Cities and the Contestation of Public Space, Urban Studies 2008.

Doxiadis, A. Constantinos. 1967. Existics: An Introduction to the Science of Human Settlement. Hutchinson, London.

Elbas, Lambertus. 1986.Arsitektur Tradisional Daerah Kalimantan Tengah.Departemen Pendidikan dan KebudayaanProyek Inventarisasi dan Dokumentasi Kebudayaan Daerah, Jakarta.

Haryadi dan Setiawan, B. 2010. Arsitektur Lingkungan dan Prilaku Dirjen Pendidikan Tinggi Departeman Pendidikan dan Kebudayaan

Indonesia Heritage. 1992. Halaman:8-9. Warisan Arsitektur Nusantara Indonesia.

Krier, Rob. 1979. Urban Space, Academy Edition, London

McKinnon, Kathy, tj. Tjitrosoepeno. 1993. Ekologi Kalimantan, Seri Ekologi Indonesia, Pretahallindo, Jakarta.

Koentjaraningrat.1991.Manusia dan Kebudayaan di Indonesia. Penerbit Djambatan, Jakarta.

Miksic, John. 1996. Indonesian Heritage, Ancient History, Published by Buku Antar bangsa (Jakarta) from Grolier International, Inc.

Maleong, Lexy J. 1999.Metodologi Penelitian Kualitatif. Remaja Resdakarya, Bandung.

Menteri Negara Lingkungan Hidup. 2000: hal.25. Pengertian Permukiman.

Noor Hamidah. 2012.Potensi Permukiman Kawasan Tepian Sungai Kahayan, Palangkaraya.Jurnal Inersia-Universitas Negeri Yogyakarta, Vol. 2 No.2, Desember 2012.

Noor Hamidah. 2013.Tugas Mandiri Kajian Teoritik Permukiman Informal Tepian Sungai. Fakultas Geografi, UGM.

Payne, G. K. 1989. Informal Housing and land subdivisions in Third world cities: A Review of the Literature. Oxford: Center for Development and Environmental Planning/CENDEP.

Poniman Aris, Nurwadjedi, dan Suwahyuono. Penyediaan Informasi Spasial Lahan Basah Untuk Mendukung Pembangunan Nasional. Forum Geografi, Vol. 20. No. 2, Desember 2006: 120-1134.

Rapoport A. 1969. House, Form and Culture. Prentice Hall Inc. Englewood Cliffs, New York.

Ritohardoyo. 1999. Geografi permukiman : Pengertian, klasifikasi, perumahan dan pola permukiman, hand out, fakultas geografi UGM, Yogyakarta

Shirvani, Hamid. 1985 The Urban Design Process. New York : Van Nastrand Reinhold Company

Tatau Wijaya. 2011.Bentuk permukiman tepian sungai kahayan ditinjau dari elemen fisik kawasan dan faktor-faktor pengaruhnya, Prosiding KABOKA 6 Universitas Palangkaraya.

Tjilik Riwut, 1979.Kalimantan Membangun. Penerbit Pustaka Jaya, Jakarta.

Tjuk Koeswartojo. 2005. Perumahan dan Permukiman di Indonesia. Penerbit ITB-Bandung

Trancik Roger. 1986. Finding Lost SpaceThe Theories of Urbang Design. New York Van Nastrand Reinhold Company

Turner, J.F.C. 1972. Housing By People. Toward Autonomous in Building Environment, New York: Pantheon Books

Undang-undang Republik Indonesia Nomor 4. Tahun 1992 tentang Perumahan dan Permukiman.

U. Cohen dan LV. Ryzim. 1989 : page.531. Metode Penelitian.

Van der Zee. 1990. Uncontrolled Settlement: Problem and Policies International Social Development Review No.1 United Nations, New York.

Wijanarka.2001.Dasar-dasar Konsep Pelestarian dan Pengembangan Kawasan Tepi Sungai di Palangka Raya. Program Pasca Sarjana Universitas Diponegoro, Semarang 